\title{
The effect of local environmental heterogeneity on species diversity of alpine dung beetles (Coleoptera: Scarabaeidae)
}

\author{
Matteo NEGRO ${ }^{1}$, Claudia PALESTRini ${ }^{1}$, Maria Teresa GiRAUdO² and Antonio ROLANDO ${ }^{1}$ \\ ${ }^{1}$ Dipartimento di Biologia Animale e dell’Uomo, Università degli Studi di Torino, via Accademia Albertina 13, 10123 Torino, Italy; \\ e-mail: matteo.negro@unito.it \\ ${ }^{2}$ Dipartimento di Matematica, Università degli Studi di Torino, via Carlo Alberto 10, 10123 Torino, Italy
}

\begin{abstract}
Key words. Beetles, Scarabaeidae, additive diversity partitioning, Generalized Linear Models, habitat heterogeneity, IndVal
\end{abstract}
\begin{abstract}
The relative effects of two components of mountain environmental heterogeneity, altitude (1500, 1700 and $2000 \mathrm{~m}$ a.s.1.) and habitat (pastures, coniferous forests, wet meadows, scrub and anthropogenic woods) on the diversity of dung beetles in an Italian alpine valley were determined. The additive gamma diversity analysis indicated that differences among habitats $\left(\beta_{\mathrm{H}}\right)$ were always smaller than those among altitudes $\left(\beta_{\mathrm{A}}\right)$, irrespective of the measures used; it also showed that the contribution of $\beta_{\mathrm{A}}$ to $\gamma$-diversity was higher than expected by chance for all the measures of species diversity used, whereas the contribution of $\beta_{\mathrm{H}}$ was significantly higher in the case of one measure only. Generalized linear models confirmed that altitude was the most important factor associated with local diversity, with all the diversity parameters considered progressively and significantly increasing with increasing altitude. Indicator species analyses revealed that dung beetle altitudinal and habitat diversity patterns depended on local choice of species, with preferences for altitudinal levels being more numerous and apparent than those for habitats. Despite the minor effect of habitat differences, comparing a three-habitat with a single-habitat scenario it was possible to demonstrate that greater habitat heterogeneity is associated with a significantly greater diversity of dung beetles. This study suggests that preservation of local environmental heterogeneity by means of traditional pastoral activities should be encouraged as a means of conserving the diversity of dung beetle species in the Alps.
\end{abstract}

\section{INTRODUCTION}

Alpine landscapes are some of the most diverse in Europe thanks to an ancient history of human settlement and the climatic constraints imposed by steep altitudinal gradients. Among human activities, in particular, pastoral activities, which have been practiced for at least 6000 years (Lichtenberger, 1994), have shaped the alpine environment. Today, as a consequence, in most of the mountain belt (below the tree line), the alpine landscape consists of a mosaic of herbaceous, shrubby and forest habitats (Errouissi et al., 2004). The distribution of alpine habitats is also controlled by altitudinal gradients, with vegetation dramatically changing along these gradients, from mid-altitude coniferous forests to high-altitude prairies and pastures.

Several studies have shown that habitat heterogeneity is associated with an increase in overall animal diversity (Beaufoy et al., 1994; Pain \& Pienkowski, 1997; Laiolo et al., 2004; Negro et al., 2007; Zahn et al., 2007). These results agree with the so called habitat heterogeneity hypothesis, which predicts that more animal species will occur in vegetation where different forms and species of plants provide greater structural heterogeneity (Hart \& Horwitz, 1991; Dennis et al., 1998).

Dung beetles (Coleoptera: Scarabaeidae) are undoubtedly one of the most typical and ecologically relevant insects in grazed alpine habitats. By exploiting faeces as a source of food they have an important role in many ecological processes (Hanski, 1991; Nichols et al., 2008).
BEF (Biodiversity and Ecosystem Functioning) studies (Loreau et al., 2001; Hooper et al., 2005; O'Connor \& Crowe, 2005) indicate that the decline or local extinction of these insects may have significant short and long term affects on ecosystem processes (Nichols et al., 2008).

Dung beetle species may show specific local habitat preferences (Barbero et al., 1999; Macagno \& Palestrini, 2009), which may nevertheless differ from area to area, suggesting a certain degree of ecological flexibility. Moreover, several studies conducted in Europe (MartínPiera et al., 1992; Romero-Alcaraz \& Ávila, 2000; Menéndez \& Gutiérrez, 2004) have shown that habitat selection usually does not depend upon vegetation structure per se, but upon related microclimatic conditions (mainly temperature and humidity).

Change in land use by humans may be directly or indirectly responsible for the degree of local habitat heterogeneity. Pastoral abandonment, in particular, may significantly affect the local landscape. In such a situation, ungrazed (or under-grazed) grassland, as a result of succession, gradually turns into scrub and, ultimately, forest. This may have consequences for dung beetles assemblages, since most Palearctic dung beetles are known to prefer open habitats (Galante et al., 1995; Jay-Robert et al., 2008).

In addition, the distribution and zonation of dung beetle families and species is strongly associated with altitude (Jay-Robert et al., 1997, 2008). In the Alps, in particular, Scarabeidae, colonize warmer and lower south-facing non-forested habitats (Lumaret \& Kirk, 1991; Lobo et al., 
2002), whereas most Geotrupidae and Aphodiidae are predominant in the colder north-facing alpine habitats at higher altitudes (Hanski, 1991; Errouissi et al., 2004).

In this paper, the effect of environmental heterogeneity (namely altitude and habitat) on dung beetle assemblages in an alpine valley on the Italian side of Monte Bianco, are described. By means of appropriate samplings the relative effects of altitude and habitat on local diversity were separately evaluated. Moreover, assuming that habitat diversity can be modified by specific pastoral activities, the effect the hypothetical disappearance of some local habitats might have on diversity was determined. Different analytical methods (additive partition of diversity, richness estimation, generalized linear models and Indicator Species Analysis) were used to describe patterns and unveil processes in local dung beetle diversity.

\section{MATERIAL AND METHODS}

\section{Study area and dung beetle sampling}

This study was carried out in the Ferret valley, an alpine valley on the Italian side of the Monte Bianco massif, at the head of the Aosta valley $\left(45^{\circ} 50^{\prime} 60^{\prime \prime} \mathrm{N} ; 7^{\circ} 01^{\prime} 00^{\prime \prime} \mathrm{E}\right)$. The climate in Ferret valley is continental with mean temperatures varying from $1.3^{\circ} \mathrm{C}$ in the coldest (January) to $15.8^{\circ} \mathrm{C}$ in the warmest month (August). Annual rainfall $(957 \mathrm{~mm}$ average) could be defined as "Mediterranean" with two peaks, one in May and the other in October and two minima in July and December January (Focarile, 1987). The entire area on the left side of the valley has been declared a Site of Community Importance (S.C.I.) (IT1204010) with the main conservation aim of protecting the glacial and wet meadows of the Monte Bianco massif. Six habitats: pastures (dominated by Gramineae), coniferous forests (dominated by larch, Larix decidua), wet meadows (on a small waterlogged plateau, the remains of a large moraine lake now completely buried), scrub (alpine rose, Rhododendron ferrugineum L. and bilberry Vaccinium myrtillus L.) and anthropogenic woods for picnickers (groves of larch trees with wooden tables, cooking and parking facilities) were investigated.

Every habitat considered in this study was grazed by cattle during the period they were sampled (120 cows throughout the entire Ferret valley).

To evaluate the relative effect of altitude on local dung beetle diversity, habitat was kept constant by sampling the same habitat (pasture) at different altitudes $(1500,1700$ and $2000 \mathrm{~m}$ a.s.1.). To determine the effect of habitat the altitude was kept constant by sampling different habitats (five sites representative of pastures, coniferous forests, wet meadows, scrub and anthropogenic woods) at the same altitude (1700 $\mathrm{m}$ a.s.l.).

Given that assemblages at sites with different geographic exposures can be significantly different (Errouissi et al., 2004), sites with the same exposure (north-northwest) were selected.

Pitfall traps of the hang-bait type, (Palestrini et al., 2008; Macagno \& Palestrini, 2009), with a mouth diameter of $7.5 \mathrm{~cm}$ and depth of $9 \mathrm{~cm}$; baited with $100 \mathrm{~g}$ of cattle dung and filled with $150 \mathrm{ml}$ of a standard mixture of water, liquid soap and sodium chloride solution to preserve the insects caught, were used.

There were three traps spaced $30 \mathrm{~m}$ apart at each site. Traps were set at the beginning of June 2007 and emptied every week until the end of October 2007; a total of 399 samples (three traps $\times$ seven sites $\times$ nineteen sampling periods) were collected.
Dung beetles caught were sorted and identified to species using updated standard keys (Pesarini, 2004; Dellacasa \& Dellacasa, 2006; Paulian \& Baraud, 1982) or specialist publications.

\section{Data analysis}

To estimate the expected species richness at each site, the abundance-based richness estimator (ACE) was used. Inventory completeness for each site was measured as the percentage of the total number of species predicted by the estimator that were actually recorded. The richness estimator was computed using EstimateS 8.0.0 (Colwell, 2006). Species for which very few individuals $(\mathrm{N}<10)$ were recorded were not included in the statistical analysis.

\section{Additive partitioning of gamma diversity}

The total diversity $(\gamma)$ recorded in the Ferret valley was additively decomposed into the mean diversity within samples $(\alpha)$ and diversity among samples ( $($ ) using the computer program PARTITION (Veech \& Crist, 2007). Additive partitioning is based on the simple relationship that alpha and beta sum to gamma $(\gamma=\alpha+\beta)$ and that species diversity can be partitioned at each level or scale of hierarchical sampling schemes in which samples at level $\mathrm{j}$ are nested within samples at level $\mathrm{j}+1$. Given this experimental design, the total amount of diversity $(\gamma)$ was calculated separately for habitats and altitudes, using catches of single traps as samples.

The three most widely used measures of species diversity [i.e. species richness (R), Shannon-Wiener Index $\left(H^{\prime}=-\Sigma p_{i} \times \ln p_{i}\right.$ where $p_{i}$ is the relative frequency of species i) and Simpson Index $\left(\mathrm{Si}=\Sigma \mathrm{p}_{\mathrm{i}}^{2}\right)$ ] were used (Lande, 1996).

Shannon-Wiener and Simpson indices measure both the number of species (species richness) and the combined effect of richness and species relative abundance (Pielou, 1969).

Total habitat diversity was decomposed into its average components, i.e. within $\left(\alpha_{\mathrm{H}}\right)$ and among $\left(\beta_{\mathrm{H}}\right)$ habitats so that $\gamma_{\mathrm{H}}=\alpha_{\mathrm{H}}$ $+\beta_{\mathrm{H}}$. To further investigate habitat diversity patterns, the average within-habitat diversity parameters $\left(\alpha_{\mathrm{H}}\right)$ was decomposed into the within $\left(\alpha_{\mathrm{P}}\right)$ and among pitfall-trap $\left(\beta_{\mathrm{P}}\right)$ components, $\alpha_{\mathrm{H}}=\mathrm{a}_{\mathrm{P}}+\beta_{\mathrm{P}}$, so that, by substitution, the overall hierarchical partition becomes $\gamma_{\mathrm{H}}=\alpha_{\mathrm{P}}+\beta_{\mathrm{P}}+\beta_{\mathrm{H}}$ (Crist \& Veech, 2006; Crist et al., 2003). The same procedure was used to decompose altitudinal $\gamma$-diversity (the model was $\gamma_{\mathrm{A}}=\alpha_{\mathrm{P}}+\beta_{\mathrm{P}}+\beta_{\mathrm{A}}$ ).

The sample-based randomization procedure in PARTITION was used to test whether the observed partitions of diversity could have been obtained by a random allocation of lower level samples nested among higher-level samples (Crist et al., 2003).

\section{Differences among habitats and altitudes}

To test for differences in diversity among habitats and altitudes individuals collected in each trap (i.e. single traps as samples) and calculated abundance $(\mathrm{N})$ and species richness (S) were considered. Given that parametric tests could not be properly employed because several assumptions were not met (homoscedasticity was violated and error terms were not always normally distributed), generalized linear models (GLM) were used. For each analysis two categorical factors (habitat type or altitude and sampling period) were considered. The best distribution to describe abundance and species richness was found to be the Poisson distribution; therefore this distribution of errors was assumed and the density of ground-dwelling arthropods was related to explanatory variables via a logarithmic link function (McIntyre \& Lavorel, 1994).

Tests for the significance of the effects in the models were done using the Wald statistic (Dobson, 1990). Such statistics are based on the asymptotic normality property of maximum likelihood estimates and computed as the generalized inner product 
TABLE 1. Number of individuals and species of dung beetle collected at seven sites. Shannon diversity $\left(\mathrm{H}^{\prime}\right)$, total number $(\mathrm{N})$, observed richness (S) and ACE estimate of expected richness (A) are provided for each site (each represented by a unique combination of habitat and altitude). Inventory completeness is observed richness as a percentage of total expected richness.

\begin{tabular}{|c|c|c|c|c|c|c|c|c|}
\hline Habitat & Shrubbery & $\begin{array}{c}\text { Wet } \\
\text { meadow }\end{array}$ & Forest & $\begin{array}{l}\text { Anthropo- } \\
\text { genic wood }\end{array}$ & Pasture & Pasture & Pasture & Total \\
\hline Altitude & 1700 & 1700 & 1700 & 1700 & 1700 & 2000 & 1500 & \\
\hline \multicolumn{9}{|l|}{ APHODIIDAE } \\
\hline Acrossus depressus (Kugelann, 1792) & 512 & 211 & 283 & 268 & 374 & 273 & 68 & 1989 \\
\hline Acrossus rufipes (Linnaeus, 1758) & 134 & 45 & 229 & 192 & 983 & 580 & 1 & 2164 \\
\hline Agoliinus satyrus (Reitter, 1892) & 148 & 103 & 201 & 78 & 55 & 207 & 0 & 792 \\
\hline Agolius abdominalis (Bonelli, 1812) & 2 & 2 & 0 & 0 & 8 & 14 & 0 & 26 \\
\hline Amidorus immaturus (Mulsant, 1842) & 1 & 2 & 1 & 1 & 0 & 14 & 0 & 19 \\
\hline Amidorus obscurus (Fabricius, 1792) & 91 & 273 & 28 & 4 & 154 & 702 & 9 & 1261 \\
\hline Aphodius fimetarius (Linnaeus, 1758) & 4 & 13 & 11 & 4 & 17 & 4 & 1 & 54 \\
\hline Bodilopsis rufa (Moll, 1782) & 38 & 53 & 131 & 129 & 107 & 15 & 9 & 482 \\
\hline Colobopterus erraticus (Linnaeus, 1758) & 7 & 153 & 10 & 3 & 41 & 25 & 25 & 264 \\
\hline Esymus pusillus (Herbst, 1789) & 0 & 2 & 6 & 6 & 0 & 0 & 25 & 39 \\
\hline Euheptaulacus carinatus (Germar, 1824) & 0 & 0 & 1 & 0 & 1 & 0 & 0 & 2 \\
\hline Limarus zenkeri (Germar, 1813) & 0 & 0 & 0 & 0 & 0 & 0 & 3 & 3 \\
\hline Oromus alpinus (Scopoli, 1763) & 354 & 125 & 21 & 13 & 134 & 1533 & 7 & 2187 \\
\hline Otophorus haemorhoidalis (Linnaeus, 1758) & 4 & 15 & 4 & 0 & 54 & 2 & 2 & 81 \\
\hline Parammoecius corvinus (Erichson, 1848) & 10 & 1 & 195 & 68 & 0 & 0 & 7 & 281 \\
\hline Planolinus fasciatus (Oliver, 1789) & 66 & 201 & 342 & 119 & 40 & 156 & 5 & 929 \\
\hline Rhodaphodius foetens (Fabricius, 1787) & 0 & 1 & 1 & 1 & 0 & 0 & 0 & 3 \\
\hline $\begin{array}{l}\text { Teuchestes fossor (Linnaeus, 1758) } \\
\text { SCARABAEIDAE }\end{array}$ & 4 & 21 & 16 & 1 & 33 & 12 & 5 & 92 \\
\hline Onthophagus baraudi Nicolas, 1964 & 0 & 1 & 6 & 0 & 7 & 0 & 0 & 14 \\
\hline $\begin{array}{l}\text { Onthophagus fracticornis (Preyssler, 1790) } \\
\text { GEOTRUPIDAE }\end{array}$ & 83 & 132 & 194 & 80 & 98 & 43 & 169 & 799 \\
\hline Anoplotrupes stercorosus (Scriba, 1796) & 31 & 20 & 1 & 0 & 11 & 3 & 2 & 68 \\
\hline Geotrupes stercorarius (Linnaeus, 1768) & 2 & 11 & 3 & 4 & 10 & 3 & 1 & 34 \\
\hline Diversity $\left(\mathrm{H}^{\prime}\right)$ & 1.93 & 2.30 & 2.16 & 1.99 & 1.86 & 1.67 & 1.69 & 2.25 \\
\hline Total number $(\mathrm{N})$ & 1491 & 1385 & 1684 & 971 & 2127 & 3586 & 339 & 11583 \\
\hline Observed richness (S) & 17 & 20 & 20 & 16 & 17 & 16 & 16 & 22 \\
\hline $\operatorname{ACE}(\mathrm{A})$ & 17.51 & 23.00 & 24.10 & 17.80 & 17.37 & 16.00 & 17.80 & 22.00 \\
\hline Completeness (\%) & 97 & 87 & 83 & 90 & 98 & 100 & 90 & 100 \\
\hline
\end{tabular}

of the parameter estimates with the respective variancecovariance matrix. Moreover, the habitat and altitude factor estimates, their standard errors and individual statistical significance were explored. Generalized linear models with categorical variables and Wald statistics were calculated using the STATISTICA 6.0 package (StatSoft Italia, 2001). According to this package, if one selects to use the sigma-restricted parameterization the last category that is specified for a categorical variable is the reference category (or level) and hence only pair wise comparisons between the effects of the remaining levels of the predictor variable on the response (dependent variable) are allowable. According to the parameterization chosen the estimation of each parameter refers to the additional effect on the dependent variable of a particular level of the considered predictor, depending on the link function chosen, with respect to the reference category and holding the other possible predictors at a constant level.

In the parameter estimation analysis, anthropogenic woods and intermediate altitudes (1700 $\mathrm{m}$ a.s.l.) were used as the reference categories for habitat and altitude, respectively.

Indicator Species Analysis (IndVal)

Specificity and fidelity of every dung beetle species within habitats and altitudes were explored using the IndVal (Indicator Value) procedure (Dufrêne \& Legendre, 1997). The indicator values are highest (100) when all individuals of a species are found in a single habitat (high specificity) and when the species occurs in all samples of that habitat (high fidelity). The statistical significance of the maximum indicator value was evaluated by a Monte Carlo randomization test (1000 runs). IndVal analyses were run using PC-Ord software (McCune \& Mefford, 1999).

Testing for the effect of habitat heterogeneity

To test whether greater habitat heterogeneity induces greater dung beetle diversity, a three-habitat scenario (i.e. pastures, coniferous forests and wet meadows, i.e. the most extensive and characteristic habitats in the Ferret valley) were compared with a single-habitat one (i.e. pastures, the typical, standard dung beetle habitat in the western Alps) at the same altitude (1700 m a.s.l.). For each period $(\mathrm{n}=19)$, abundance, species richness and $\mathrm{H}^{\prime}$ diversity (Shannon-Wiener index) were calculated for each site using a three-trap sample (i.e. using all beetles caught by the three traps at a site as a sample). In the case of the single habitat scenario, all three traps placed in that habitat were considered, whereas in the case of the three-habitat scenario one trap at a time for each of the three habitats was considered. There are 27 different possible combinations of three given traps, obtained by drawing one trap at a time from each of the three groups of three traps (i.e. $3^{3}=27$ ). Therefore, for each measure, differences between the one-habitat and three-habitat samples (with 19 sam- 

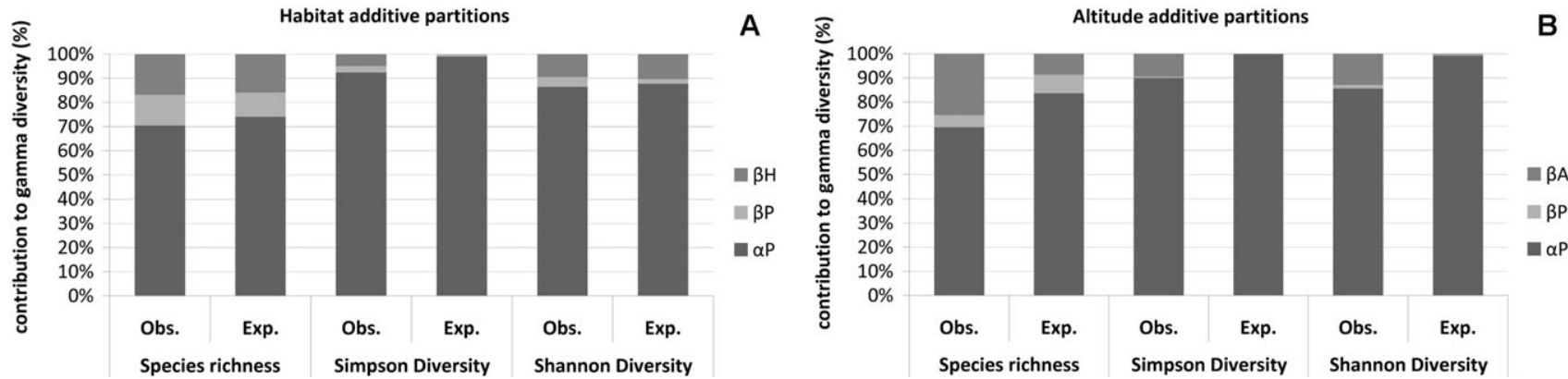

Fig. 1. Additive partition across five habitats (A) and three altitudes (B), using three measures of species diversity (species richness, Simpson index and Shannon index). Values are expressed as the percentage of the total gamma diversity $(\gamma)$ explained by each hierarchical level. The observed partitions are compared with expected values from individual-based randomizations. $\alpha_{\mathrm{P}}, \beta_{\mathrm{P}}=$ pitfall traps; $\beta_{\mathrm{H}}=$ habitat types; $\beta_{\mathrm{A}}=$ altitudes.

pling units in either group) were tested 27 times (Wilcoxon signed-rank tests).

\section{RESULTS}

A total of 22 species of dung beetle (corresponding to 11,583 individuals) were collected. As most of the expected species (ranging form 83 to $100 \%$ ) were caught at each site the sampling effort was sufficient for correctly describing the local assemblages of dung beetles (Table 1). The dung beetle assemblage was strongly dominated by Aphodiidae $(92.1 \%$ of the sampled individuals), whereas Scarabaeidae and Geotrupidae were much less abundant (respectively 7.0 and $0.9 \%$ ).

Limarus zenkeri, Euheptaulacus carinatus and Rhodaphodius foetens were not included in the statistical analysis because of the very low numbers of individuals collected (respectively 3, 2 and 3; Table 1).

\section{Additive partitioning of $\boldsymbol{\gamma}$-diversity}

Diversity within pitfall traps $\left(\alpha_{\mathrm{P}}\right)$ contributed most to both total habitat and altitude $\gamma$-diversity, irrespective of the measures of diversity used (ranging from $69.5 \%$ to $92.4 \%$ ), whereas diversity among pitfall traps $\left(\Omega_{\mathrm{P}}\right)$ contributed least (ranging from $0.49 \%$ to $12.73 \%$ ).

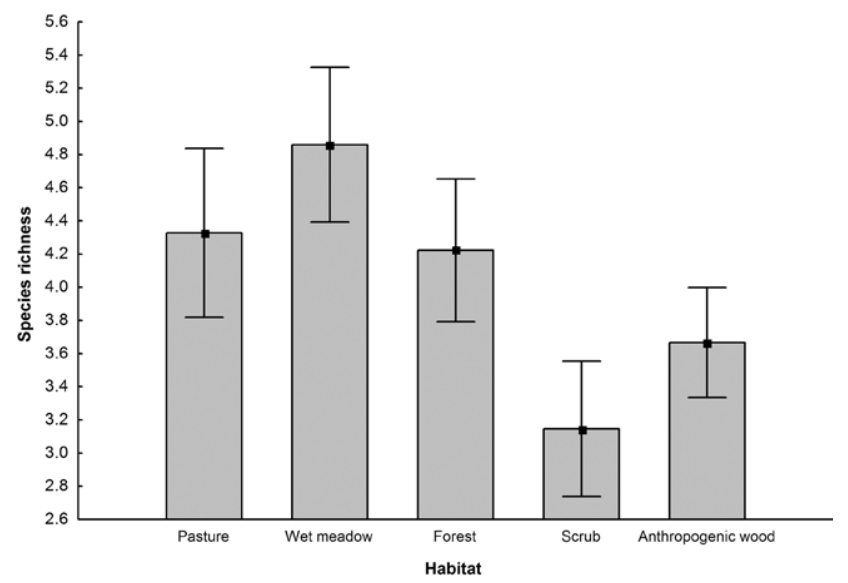

Fig. 2. Mean values of species richness (number of species / number of traps) recorded for five habitats. Bars are \pm standard errors.
Differences among habitats $\left(\beta_{\mathrm{H}}\right)$ were always smaller than those among altitudes $\left(\aleph_{\mathrm{A}}\right)$, irrespective of the measures of diversity considered (Fig. 1A, B). A randomization procedure showed that the contribution of $\alpha_{P}$ and $\beta_{P}$ to $\gamma$-diversity was never significantly different from that expected by chance. Vice-versa, the contribution of $\beta_{\mathrm{A}}$ to $\gamma$-diversity was higher than that expected by chance $(\mathrm{P}<$ 0.001 ) for all the measures of diversity used, whereas the contribution of $\beta_{\mathrm{H}}$ was significantly higher only in the case of the Simpson diversity index.

TABLE 2. Indicator Species Analysis (IndVal) calculated for five habitats. Maximum observed value and mean expected $( \pm$ SD) indicator value are given. Statistical significance obtained using the Monte Carlo randomization test (1000 runs). ${ }^{*} \mathrm{P}<$ $0.05 ; * * \mathrm{P}<0.01 ; * * * \mathrm{P}<0.001$. Note that no species selected anthropogenic woods.

\begin{tabular}{|c|c|c|c|c|}
\hline & \multirow{2}{*}{$\begin{array}{c}\text { Observed } \\
\text { Indicator } \\
\text { Value (IV) }\end{array}$} & \multicolumn{2}{|c|}{$\begin{array}{l}\text { IV from ran- } \\
\text { domized groups }\end{array}$} & \multirow[t]{2}{*}{$\mathrm{p}$} \\
\hline & & Mean & S. Dev & \\
\hline \multicolumn{5}{|l|}{ No habitat selection } \\
\hline Agolius abdominalis & 1.3 & 2.4 & 1.22 & N.S \\
\hline Acrossus depressus & 8.7 & 13 & 2.5 & N.S \\
\hline Aphodius fimetarius & 5.1 & 4.8 & 1.58 & N.S \\
\hline Amidorus immaturus & 0.5 & 1.9 & 1.1 & N.S \\
\hline Agoliinus satyrus & 15.5 & 11.7 & 2.13 & N.S \\
\hline Bodilopsis rufa & 10.7 & 10.7 & 2.22 & N.S \\
\hline Esymus pusillus & 4.3 & 2.8 & 1.26 & N.S \\
\hline Geotrupes stercorarius & 5.6 & 4.2 & 1.45 & N.S \\
\hline $\begin{array}{l}\text { Teuchestes fossor } \\
\quad \text { Pasture }\end{array}$ & 7.2 & 5.2 & 1.69 & N.S \\
\hline Acrossus rufipes & 31.5 & 14.9 & 3.52 & $* *$ \\
\hline Onthophagus baraudi & 5.4 & 2.7 & 1.28 & $*$ \\
\hline $\begin{array}{l}\text { Otophorus haemorhoidalis } \\
\text { Shrubbery }\end{array}$ & 16.7 & 6.6 & 2.4 & $* *$ \\
\hline Anoplotrus stercorosus & 9 & 4.8 & 1.58 & $*$ \\
\hline $\begin{array}{l}\text { Oromus alpinus } \\
\text { Wet meadow }\end{array}$ & 32 & 12.5 & 2.53 & $* *$ \\
\hline Amidorus obscurus & 22.2 & 10.9 & 2.39 & $* *$ \\
\hline $\begin{array}{l}\text { Colobopterus erraticus } \\
\text { Forest }\end{array}$ & 33.5 & 7.5 & 1.96 & $* *$ \\
\hline Onthophagus fracticornis & 17.4 & 13.2 & 2.04 & $*$ \\
\hline Parammoecius corvinus & 34.3 & 8.5 & 2.33 & $* *$ \\
\hline Planolinus fasciatus & 21 & 12 & 2.2 & $* *$ \\
\hline
\end{tabular}




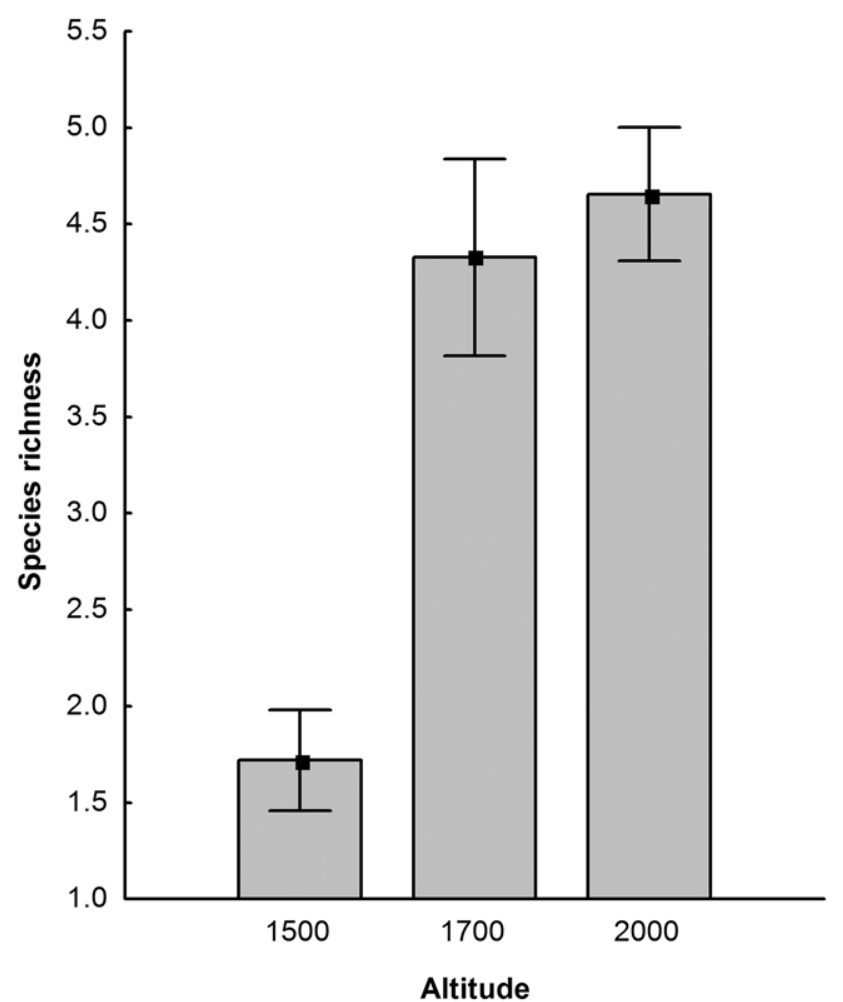

Fig. 3. Mean values of species richness (number of species / number of traps) recorded at three altitudes. Bars are \pm standard errors.

\section{Differences among habitats and altitudes}

Abundance and species richness significantly differed among habitats, altitudes and periods $(\mathrm{P}<0.001)$. Habitat estimates, in particular, showed that abundance and species richness associated with anthropogenic woods (set as a reference category) were significantly lower than those of wet meadows $(\mathrm{N}$ : Estimates $=0.15$, Wald stat $=7.87, \mathrm{P}$ $<0.01$; S: Est. $=0.33$, Wald stat $=19.10, \mathrm{P}<0.001)$ and pastures $(\mathrm{N}$ : Est. $=0.27$, Wald stat $=21.80, \mathrm{P}<0.01)$; but higher than those associated with scrub $(\mathrm{N}$ : Est. $=-0.30$, Wald stat $=6.36, \mathrm{P}<0.05$; S: Est. $=-0.35$, Wald stat $=$ 7.17, $\mathrm{P}<0.01$ ) (Fig. 2).

Altitude estimates depicted a well-defined trend, with both abundance and species richness progressively and significantly increasing with increasing altitude. The parameters associated with the $1700 \mathrm{~m}$ altitude (set as a reference category) were significantly lower than those of the $2000 \mathrm{~m}$ altitude $(\mathrm{N}$ : Est. $=0.78$, Wald stat $=350.76, \mathrm{P}$ $<0.001$; S: Est. $=0.33$, Wald stat $=19.36, \mathrm{P}<0.001)$ and higher than those of the $1500 \mathrm{~m}$ altitude $(\mathrm{N}$ : Est. $=-1.03$, Wald stat $=440.66, \mathrm{P}<0.001$; S: Est. $=-0.57$, Wald stat $=41.59, \mathrm{P}<0.001$ ) (Fig. 3).

\section{Indicator Species Analysis}

The analysis of indicator species using IndVal showed that nine species did not show a clear preference for a particular habitat. The other species were evenly distributed among the natural habitats: three species preferred pastures, two scrub, two wet meadows and three conif-
TABLE 3. Indicator Species Analysis (IndVal) calculated for three altitudes. Maximum observed value and mean expected ( \pm $\mathrm{SD})$ indicator value are given. Statistical significance obtained using the Monte Carlo randomization test (1000 runs). ${ }^{*} \mathrm{P}<$ $0.05 ; * * \mathrm{P}<0.01 ; * * * \mathrm{P}<0.001$.

\begin{tabular}{|c|c|c|c|c|}
\hline & \multirow{2}{*}{$\begin{array}{c}\text { Observed } \\
\text { Indicator } \\
\text { Value (IV) }\end{array}$} & \multicolumn{2}{|c|}{$\begin{array}{l}\text { IV from random- } \\
\text { ized groups }\end{array}$} & \multirow{2}{*}{$\mathrm{p}$} \\
\hline & & Mean & S. Dev & \\
\hline \multicolumn{5}{|l|}{ No altitude selection } \\
\hline Acrossus depressus & 14.7 & 15.2 & 3.19 & N.S. \\
\hline Colobopterus erraticus & 9.5 & 9 & 2.64 & N.S. \\
\hline $\begin{array}{l}\text { Teuchestes fossor } \\
1500 \mathrm{~m} \text { a.s. } 1 .\end{array}$ & 10.4 & 7.2 & 2.24 & N.S. \\
\hline Esymus pusillus & 12.3 & 3.7 & 1.63 & $* * *$ \\
\hline Onthophagus fracticornis & 25.8 & 17.9 & 2.99 & $*$ \\
\hline $\begin{array}{l}\text { Parammoecius corvinus } \\
1700 \text { m a. s. } 1 .\end{array}$ & 10.5 & 3.2 & 1.44 & $* *$ \\
\hline Acrossus rufipes & 30.9 & 17.3 & 3.82 & $* *$ \\
\hline Anoplotrus stercorosus & 9.6 & 5.2 & 1.85 & $*$ \\
\hline Aphodius fimetarius & 10.8 & 5.3 & 1.93 & $*$ \\
\hline Bodilopsis rufa & 31.5 & 10.7 & 2.65 & $* * *$ \\
\hline Geotrupes stercorarius & 10 & 4.9 & 1.81 & $*$ \\
\hline Onthophagus baraudi & 10.5 & 3.2 & 1.47 & $*$ \\
\hline $\begin{array}{l}\text { Otophorus haemorhoidalis } \\
2000 \mathrm{~m} \text { a. s. } 1 .\end{array}$ & 21.2 & 7.5 & 2.64 & $* * *$ \\
\hline Agoliinus satyrus & 47.1 & 14.2 & 2.98 & $* * *$ \\
\hline Agolius abdominalis & 11.2 & 5 & 2.03 & $*$ \\
\hline Amidorus immaturus & 17.5 & 4.5 & 1.77 & $* * *$ \\
\hline Amidorus obscurus & 61.2 & 20.2 & 3.11 & $* * *$ \\
\hline Oromus alpinus & 62.7 & 20.7 & 4.19 & $* * *$ \\
\hline Planolinus fasciatus & 24.5 & 11.7 & 2.75 & $* * *$ \\
\hline
\end{tabular}

erous forest (Table 2). No species positively selected anthropogenic woods.

Altitudinal choices depicted a rather clear altitudinal pattern, with four distinct groups: (1) species of low altitudes, which were found mainly at $1500 \mathrm{~m}$. a.s.l.; (2) species of medium altitudes, which were found mainly at 1700 m. a.s.l.; (3) species of high altitudes, which were found mainly at $2000 \mathrm{~m}$. a.s.l. and (4) species with no altitude preference, which occurred at all altitudes (Table 3).

\section{Testing the effect of habitat heterogeneity}

Median values of the Shannon-Wiener index and species richness of the three-habitat scenario were significantly greater than that of the single-habitat scenario in all instances, that is, irrespective of the combinations of traps used $(n=27)$. Conversely, median values of abundance were significantly higher only in 10 instances out of 27 ; given that the proportion of significant differences $(10 / 27$ $=0.37$ ) was higher than 0.05 , abundance was not considered to be significantly affected by habitat heterogeneity.

\section{DISCUSSION}

Local dung beetle diversity is generated and associated with a range of factors such as ecosystem productivity and age, climatic variability, predation, intra- and interspecific competition, latitude, altitude and habitat heterogeneity (Romero-Alcaraz \& Avila, 2000). In the Alps, in 
particular, altitude and habitat type greatly influence assemblage composition (Jay-Robert et al., 2008).

The results of the additive partitioning analysis presented here suggest that differences in altitude may have an important effect on $\beta$ diversity, irrespective of the measures of diversity used. The observed partition differs from the expected one, mostly due to differences in the $\beta$ diversity at the highest level $\left(\beta_{\mathrm{A}}\right)$. Presumably, differences between observed and expected diversity components are due to ecological processes that lead to a non-random dispersion of individuals along the altitudinal gradient, giving rise to a marked altitude selection (Veech et al., 2002). This result agrees with previous studies that show altitude is an important factor influencing community parameters (Lumaret \& Stiernet, 1991; Martín-Piera et al., 1992; Menéndez \& Gutiérrez, 1996).

GLM analyses showed that abundance and species richness were significantly and positively correlated with altitude. It is likely that this trend is due to the preponderance of Aphodiidae, which are known to colonize habitats at high altitudes in cold temperate areas (Errouissi et al., 2004; Jay-Robert et al., 2008).

The Indicator Species Analysis provided further evidence that the distribution of dung beetles in the Ferret valley is mainly associated with altitude. Most species (all belonging to the family Aphodiidae) tend to occur at intermediate and high altitudes. Additive partitioning analysis suggested that habitat was less important than altitude in structuring dung beetles assemblages, given that the only exception, which was the observed $B$ diversity values based on the Simpson Index, did not differ statistically from those expected. Differences among habitats, however, did exist. Dung beetle assemblages were more abundant and diversified in wet meadows than in other habitats. This habitat, which is peculiar to the Ferret valley, was recently included in a Site of Community Importance in order to protect it from ecological decay resulting from increased tourism. The results presented demonstrate that scrub is a suboptimal habitat for dung beetles, which accords with the findings of studies on several Mediterranean ecosystems in southern Europe (Lumaret \& Kirk, 1987; Verdú et al., 2000). Dung beetles are probably negatively affected by shrub cover because of lower resource density and where shrub cover is reduced by grazing the attractiveness of this habitat for dung beetles is likely to increase (Jay-Robert et al., 2008). IndVal analyses showed that most species did not prefer a particular habitat, thus confirming the secondary role played by habitat in comparison with altitude and indicating, at the same time, that species-specific choices (or lack of) are responsible for the diversity patterns observed. Nevertheless, each natural (or semi-natural) undisturbed habitat (i.e. pastures, coniferous forests, scrub and wet meadows) had two/three indicator species. This suggests that each undisturbed habitat in the Ferret valley may be important for the conservation of certain dung beetle species. This is in accord with the idea that it is likely that a highly complex habitat may support more potential niches for a functionally diverse suite of species and a greater range of food webs than less complex habitats (Klopfer \& MacArthur, 1960; Lassau et al., 2005). Tests conducted comparing a three-habitat scenario with a single-habitat scenario confirmed that the presence of numerous habitats is significantly associated with an increase in local dung beetle diversity.

A notable exception to this habitat selection pattern was the habitat subject to human disturbance (anthropogenic woods), which did not have any indicator species. Tourism and related infrastructure (mainly access roads and shelters) is known to negatively affect coprophagous beetle assemblages (Lobo et al., 2001). Negative effect of tourism is particularly heavy in coastal habitats; Lobo (2001) pointed out that the profound alteration of the coastal zones in the Iberian Mediterranean area for tourism (due to urban development) has contributed most to the disappearance of many roller dung beetle populations.

Therefore, habitat heterogeneity may be necessary for the conservation of alpine dung beetle diversity if it is driven by natural processes or ecologically-sustainable human activities (such as pastoral activities). Land use may drive habitat heterogeneity and, therefore, affect dung beetle diversity. The abandonment of certain rural areas and natural succession, has allowed forest regeneration, which, in the long term, homogenizes habitat conditions. Reforestation is often associated with colonization by wild ungulates, whose faeces are used by dung beetles (Barbero et al., 1999). Since the Tertiary wild mammals and dung beetles have co-evolved with several cycles of expansion and contraction (Cambefort, 1991). However, wild ungulate manure is not enough to ensure the conservation of regional dung beetle species pools (Jay-Robert et al., 2008). The contribution of pastoral activities involving livestock (such as cows, goats and sheep) is therefore essential.

Thus it is concluded that the preservation of environmental heterogeneity should be encouraged as a means of conserving dung beetles in the Alps. The maintenance of traditional pastoral activities, in particular, may significantly help preserve habitat heterogeneity and, consequently, dung beetle diversity.

ACKNOWLEDGMENTS. We are sincerely grateful to E. Barbero who kindly supervised and checked dung beetle identifications. We also express gratitude to R. Gorret and C. Tocco who helped us with the fieldwork and dung beetle preparation. M. Negro was funded by a Turin University fellowship.

\section{REFERENCES}

Barbero E., Palestrini C. \& Rolando A. 1999: Dung beetle conservation: effects of habitat and resource selection (Coleoptera: Scarabaeoidea). J. Insect Conserv. 3: 75-84.

Beaufoy G., Baldock D. \& Clark J. 1994: The Nature of Farming. Joint Nature Conservation Committee, Peterborough, UK.

CAMBefort Y. 1991: Biogeography and Evolution. In Hanski I. \& Cambefort Y. (eds): Dung Beetle Ecology. Princeton University Press, Princeton, NJ, pp. 51-67.

CRIST T.O. \& VeECH J.A. 2006: Additive partitioning of rarefaction curves and species-area relationships: unifying alpha, 
beta, and gamma diversity with sample size and area. Ecol. Lett. 9: 923-932.

Crist T.O., Veech J.A., Summerville K.S. \& Gering J.C. 2003: Partitioning species diversity across landscapes and regions: a hierarchical analysis of alpha, beta, and gamma diversity. Am. Nat. 16: 734-743.

Colwell R.K. 2006: EstimateS: Statistical Estimation of Species Richness and Shared Species from Samples. Version 8.0.0 User's Guide and application published at: http://purl.oclc. org/estimates.

Dellacasa G. \& Dellacasa M. 2006: Coleoptera, Aphodiidae, Aphodiinae. In: Fauna d'Italia. Vol. XLI. Calderini, Bologna, $484 \mathrm{pp}$.

Dennis P., Young M.R. \& Gordon I.J. 1998: Distribution and abundance of small insects and arachnids in relation to structural heterogeneity of grazed, indigenous grassland. Ecol. Entomol. 23: 253-264.

Dobson A.J. 1990: An Introduction to Generalized Linear Models. Chapman \& Hall, New York.

DufrêNE M. \& LegEndRE P. 1997: Species assemblages and indicator species: the need for a flexible asymmetrical approach. Ecol. Monogr. 67: 345-366.

Errouissi F., Jay-Robert P., Lumaret J.P. \& Piau P. 2004: Composition and structure of dung beetle (Coleoptera: Aphodiidae, Geotrupidae, Scarabaeidae) assemblages in mountain grasslands of the Southern Alps. Ann. Entomol. Soc. Am. 97: 701-709.

Focarile A. 1987: Ecologie et biogéographie des Coléoptères de haute altitude en Vallée d'Aoste: recherches sur la faune entomologique de la Vallée d'Aoste. 16me contribution. Region Autonome de la Vallée d'Aoste, Assessorato agricoltura, foreste e ambiente naturale, Servizio selvicoltura, difesa e gestione del patrimonio forestale, Aosta, $72 \mathrm{pp}$.

Galante E., Mena J. \& Lumbreras C. 1995: Dung beetles (Coleoptera: Scarabaeidae, Geotrupidae) attracted to fresh cattle dung in wooded and open pasture. Environ. Entomol. 24: $1063-1068$.

HANSKI I. 1991: North temperate dung beetles. In: Hanski I. \& Cambefort Y. (eds): Dung Beetle Ecology. Princeton University Press, Princeton, NJ, pp. 75-96.

HarT D.D. \& HoRwitz R.J. 1991: Habitat diversity and the species-area relationship: alternative models and tests. In Bell S.S., McCoy E.D. \& Mushinsky H.R. (eds): Habitat Structure: The Physical Arrangement of Objects in Space. Chapman and Hall, London, pp. 47-68.

Hooper D.U., Chapin III F.S., Ewel J.J., Hector A., Inchausti P., Lavorel S., Lawton J H., Lodge D.M., Loreau M., Naeem S., Schmid B., Setälä H. Symstad A.J., Vandermeer J. \& WARDLE D.A. 2005: Effects of biodiversity on ecosystem functioning: a consensus of current knowledge. Ecol. Monogr. 75: 3-35.

JAy-Robert P., LoBo J.M. \& Lumaret J.P. 1997: Altitudinal turnover and species richness variation in European montane dung beetle assemblages. Arctic Alpine Res. 29: 196-205.

JAY-Robert P., Lumaret J.P. \& LEBRETon J.D. 2008: Spatial and temporal variation of mountain dung beetle assemblages and their relationships with environmental factors (Aphodiinae: Geotrupinae: Scarabaeinae). Ann. Entomol. Soc. Am. 101: $58-69$.

KLopfer P.H. \& MacArthur R. 1960: Niche size and faunal diversity. Am. Nat. 94: 293-300.

Laiolo P., Dondero F., Ciliento E. \& Rolando A. 2004: Consequences of pastoral abandonment for the structure and diversity of the alpine avifauna. J. Appl. Ecol. 41: 294-304.

LANDE R. 1996: Statistics and partitioning of species diversity, and similarity among multiple communities. Oikos 76: 5-13.
Lassau S.A., Hochuli D.F., Cassis G.A. \& Reid C.A.M. 2005: Effects of habitat complexity on forest beetle diversity: do functional groups respond consistently? Divers. Distrib. 11: 73-82.

LichtenBerger E. 1994: Die Alpen in Europa. Österreochiske Academie der Wissenshaften. Veröffentlich. Kommis. Humanökol. 5: 53-86.

Lово J.M. 2001: Decline of roller dung beetle (Scarabaeinae) populations in the Iberian peninsula during the $20^{\text {th }}$ century. Biol. Conserv. 97: 43-50.

Lobo J.M., Lumaret J.P. \& Jay-Robert P. 2001: Diversity, distinctiveness and conservation status of the Mediterranean coastal dung beetle assemblage in the Regional Natural Park of the Camargue (France). Divers. Distrib. 7: 257-270.

Lobo J.M., Lumaret J.P. \& JAY-Robert P. 2002: Modeling the species richness distribution of French dung beetles and delimiting the predictive capacity of different groups of explanatory variables (Coleoptera: Scarabaeidae). Glob. Ecol. Biogeogr. Lett. 11: 265-277.

Loreau M., Naeem S., Inchausti P., Bengtsson J., Grime J.P., Hector A., Hooper D.U., Huston M.A., Raffaelli D., Schmid B., Tilman D. \& Wardle D.A. 2001: Biodiversity and ecosystem functioning: Current knowledge and future challenges. Science 294: 804-808.

LUMARET J.P. \& KIRK A.A. 1987: Ecology of dung beetles in the French mediterranean region (Coleoptera: Scarabaeinae). Acta Zool. Mex. 24: 1-55.

LuMARET J.P. \& KIRK A.A. 1991: South temperate dung beetles. In Hanski I. \& Cambefort Y. (eds): Dung Beetle Ecology. Princeton University Press, Princeton, NJ, pp. 97-115.

Lumaret J.P. \& Stiernet N. 1991: Montane dung beetles. In Hanski I. \& Cambefort Y. (eds): Dung Beetle Ecology. Princeton University Press, Princeton, NJ, pp. 242-254.

Macagno A.L.M. \& Palestrini C. 2009: The maintenance of extensively exploited pastures within the Alpine mountain belt: implications for dung beetle conservation (Coleoptera: Scarabaeoidea). Biodiv. Conserv. 18: 3309-3323.

Martín-Piera F., Veiga C.M. \& Lobo J.M. 1992: Ecology and biogeography of dung-beetle assemblages (Coleoptera, Scarabaeoidea) in an Iberian mountain range. J. Biogeogr. 19: 677-691.

McCune B. \& Mefford M.J. 1999: Multivariate Analysis of Ecological Data. Version 4.17. MjM Software, Gleneden Beach, Oregon, U.S.A.

McIntyre S. \& Lavorel S. 1994: Predicting richness of native, rare and exotic plants in response to habitat and disturbance variables across a variegated landscape. Conserv. Biol. 8: 521-531.

MenÉnDEZ R. \& GutiérReZ D. 1996: Altitudinal effects on habitat selection of dung beetles (Scarabaeoidea: Aphodiidae) in the northern Iberian Peninsula. Ecography 19: 313-317.

MeNÉnDEZ R. \& GutIÉRREZ D. 2004: Shifts in habitat associations of dung beetles in northern Spain: climate change implications. Ecoscience 11: 329-337.

Negro M., Casale A., Migliore L., Palestrini C. \& Rolando A. 2007: The effect of small-scale anthropogenic habitat heterogeneity on assemblages of macro-carabids (Coleoptera, Caraboidea) endemic to the Alps. Biodiv. Conserv. 16: 3919-3932.

Nichols E., Spector S., Louzada J., Larsen T.H., Amezquita S. \& FAVILA M.E. 2008: Review: Ecological functions and ecosystem services provided by Scarabaeinae dung beetles. Biol. Conserv. 141: 1461-1474.

O'ConNor N.E. \& CRowe T.P. 2005: Biodiversity loss and ecosystem functioning: distinguishing between number and identity of species. Ecology 86: 1783-1796. 
Pain D.J. \& Pienkowski M.W. 1997: Farming and Birds in Europe. Academic Press, London, xvi $+436 \mathrm{pp}$.

Palestrini C., Roggero A., Negro M., Quaglia E., Rovei R. \& BARBERo E. 2008: Studio sulla coleotterofauna coprofaga (Coleoptera: Scarabaeoidea) nel Parco Naturale Regionale Mont Avic (Valle d'Aosta, Italia). Rev. Valdotaine Hist. Nat. 61-62: 189-217.

Pielou E.C. 1969: An Introduction to Mathematical Ecology. Wiley, New York, viii + 286 pp.

Paulian R. \& Baraud J. 1982: Faune des coléoptères de France, II Lucanoidea et Scarabaeoidea. Lechevalier, Paris, $477 \mathrm{pp}$.

Pesarini C. 2004: Insetti della fauna italiana, Coleotteri Lamellicorni. Natura Vol. 93, Fasc. 2. Società Italiana di Scienze Naturali e Museo Civico di Storia Naturale, Milano, 130 pp.

Romero-Alcaraz E. \& Ávila J.M. 2000: Effect of elevation and type of habitat on the abundance and diversity of Scarabaeoid dung beetle (Scarabaeoidea) assemblages in a Mediterranean area from southern Iberian Peninsula. Zool. Stud. 39: 351-359.

StatSoft Italia 2001: STATISTICA Versione 6. www.statsoft.it. Veech J.A. \& CRIST T.O. 2007: PARTITION: Software for Hierarchical Additive Partitioning of Species Diversity. Version 2.0. http://www.users.muohio.edu/cristto/partition.htm

Veech J.A., Summerville K.S., Crist T.O. \& Gering J.C. 2002: The additive partitioning of diversity: recent revival of an old idea. Oikos 99: 3-9.

Verdú J.R., Crespo M.B. \& Galante E. 2000: Conservation strategy of a nature reserve in Mediterranean ecosystems: the effects of protection from grazing on biodiversity. Biodiv. Conserv. 9: 1707-1721.

Zahn A., Juen A., Traugott M. \& Lang A. 2007: Low density cattle grazing enhances arthropod diversity of abandoned wetland. Appl. Ecol. Environ. Res. 5: 73-86.

Received August 12, 2010; revised and accepted October 12, 2010 